\title{
Oral toxicity of the microcystin-containing cyanobacterium Planktothrix rubescens in European whitefish (Coregonus lavaretus)
}

\author{
Bernhard Ernst, Stefan J. Hoeger, Evelyn O’Brien, Daniel R. Dietrich* \\ Environmental Toxicology, University of Konstanz, P.O. Box X-918, D-78457 Konstanz, Germany
}

\begin{abstract}
The microcystin-producing cyanobacterium Planktothrix is one of the most widespread genera amongst toxin producing cyanobacteria in European lakes. In particular, the metalimnic blooms of Planktothrix rubescens have been associated with growing problems in the professional freshwater fishery as a decrease in yearly yields in the important coregonids fishery often coincides with the appearance of $P$. rubescens. $P$. rubescens is a cyanobacterial species known to produce toxic compounds, e.g. microcystins. Although microcystins have been reported to affect fish health, behaviour, development and growth and have also been associated with feral fish kills, there is currently no specific information on the effects of toxic Planktothrix filaments in fish and especially coregonids. Therefore, the aim of this study was to investigate the effects of an environmentally relevant dose of $P$. rubescens filaments orally applied to coregonids and to discuss the findings in the context of microcystin toxicity previously reported in carp and trout.

A single dose of $P$. rubescens culture, at a density of 80,000 cells per $120 \mu \mathrm{l}$, was applied to coregonids thus corresponding to $0.6-0.9 \mu \mathrm{g}$ microcystin- $\mathrm{LR}_{\text {equiv. }} / \mathrm{kg}$ body weight. Behavioural changes and opercular beat rates, growth, hepatosomatic index, condition and plasma glucose were determined. Liver, kidney, gill and the gastrointestinal tract were assessed histopathologically and immunhistologically. Exposed fish showed behavioural changes, increased opercular beat rates and elevated plasma glucose levels, possibly representing a physiological stress response. Histopathological alterations in liver, gastrointestinal tract and kidney, also immunopositive for microcystin suggested causality of tissue damage and the in situ presence of microcystins.

The observed combination of stress and organ damage may explain the frequently reduced weight and thus the fitness noted in coregonids subjected to regular occurrences of stratified and dispersed P. rubescens blooms, e.g. in lake Ammersee, Bavaria, Germany.
\end{abstract}

Keywords: Fish; Microcystin; Planktothrix; Coregonids; Cyanobacteria; Whitefish

\section{Introduction}

Toxic cyanobacteria occur worldwide in fresh and coastal waters. Due to their ability to produce highly toxic metabolites, i.e. the neurotoxins anatoxin, saxitoxin and the potent protein phosphatase inhibitors microcystins and nodularins, mass occurrences of cyanobacteria have been associated with human intoxications (mild to lethal) and mortality of wild and domestic animals (Briand et al., 2003; Dietrich et al., in press).

To date, at least 46 cyanobacterial species are known to produce toxins, thus it is not surprising that approximately $75 \%$ of cyanobacteria samples taken in surface waters have been shown to contain toxins (Sivonen and Jones, 1999). The microcystin-

\footnotetext{
* Corresponding author. Tel.: +49 7531 883518; fax: +49 7531883170 . E-mail address: Daniel.Dietrich@uni-konstanz.de (D.R. Dietrich).
}

producing Planktothrix is one of the most important genera amongst the widespread toxin-producing cyanobacteria in temperate climates. Planktothrix species are predominant in several monomictic and dimictic European lakes, especially in the prealpine regions (Mez, 1998; Henriksen, 2001; Utkilen et al., 2001; Lindholm et al., 2002; Morabito et al., 2002; Davis et al., 2003; Krupa and Czernas, 2003). Planktothrix sp. generally occur in eutrophic waters, building blooms during winter circulation and metalimnic layers during lake stratification in summer. Planktothrix rubescens can also occur in mesotrophic and even oligotrophic lakes that have recently undergone an anthropogenically induced phase of nutritional re-depletion (reoligotrophication) (Ernst et al., 2001; Jacquet et al., 2005). Drinking water management (Hitzfeld et al., 2000; Hoeger et al., 2005) and professional freshwater fishery (Ernst et al., 2001) have been faced with growing problems due to metalimnic blooms of $P$. rubescens. Indeed, a decrease in yearly yields in 
the important coregonids fishery was observed to coincide with the appearance of $P$. rubescens blooms in Swiss and German lakes as of the beginning of the last century (Braun, 1953; Ernst et al., 2001).

Mass occurrence of toxic cyanobacteria have been associated with feral fish kills (Toranzo et al., 1990; Rodger et al., 1994; Jewel et al., 2003). Toxic effects have been shown for various fish species, including salmoniformes, siluriformes, cypriniformes as well as perciformes and clear differences in fish species sensitivity to toxic cyanobacteria in general (as cell suspensions or bloom material) and microcystins (primarily microcystin-LR (MC-LR)) have been demonstrated (Malbrouck and Kestemont, 2006). The $\mathrm{LD}_{50}$ value for orally applied MC-LR to carp was reported to be $<1.7 \mathrm{mg} / \mathrm{kg}$ body weight (Tencalla, 1995), while the $\mathrm{LD}_{50}$ for orally applied MC-LR to trout was found to range between 1.7 and $6.6 \mathrm{mg} / \mathrm{kg}$ body weight (Tencalla et al., 1994). Similar species differences were demonstrated for intraperitoneally applied MC-LR (Råbergh et al., 1991; Tencalla et al., 1994; Carbis et al., 1996). The observed species-specific sensitivities to microcystins have been interpreted as resulting from anatomical, physiological and behavioural differences amongst the various fish orders (Tencalla, 1995; Fischer and Dietrich, 2000).

Uptake of cyanobacterial toxins by fish results primarily following oral ingestion of toxins or toxic cyanobacterial cells and to a negligible extent from toxin uptake via the gill epithelium (Tencalla et al., 1994; Bury et al., 1998). Fish exposed to cyanobacterial bloom material or acutely toxic concentrations of microcystins presented with liver, kidney and gill pathology, specific inhibition of protein phosphatases and other downstream effects, e.g. increased liver enzyme values in the serum. In addition behavioural changes and decreased development of juvenile fish have been observed (Malbrouck and Kestemont, 2006 and references therein). Most fish exposure experiments have been conducted using either pure MC-LR or MC-LR containing Microcystis aeruginosa. Compared to other cyanobacteria, Planktothrix sp. have been shown to contain the highest amounts of microcystin per gram dry weight (Fastner et al., 1999b). In contrast to $M$. aeruginosa, Planktothrix sp. contain various demethylated variants of MC-RR (Luukkainen et al., 1993; Blom et al., 2001; Keil et al., 2002). Apart from some reports on Planktothrix associated fish kills (Berg et al., 1986), there is no information on the toxicity of Planktothrix sp. filaments and demethylated MC-RR variants in fish and especially coregonids. In addition, Planktothrix sp. produce a range of other metabolites, e.g. anabaenopeptins, microviridins and cyanopeptolins (Blom et al., 2003) with yet unknown toxicological properties. Therefore, the toxic potential of Planktothrix blooms to freshwater fish, and especially coregonid, populations is presently difficult to assess.

Coregonids (Coregonus sp.), one of the most important species for professional fishery, are among the dominant fish species in most of the stratified European lakes. Ernst et al. (2001) proposed a possible link between the occurrence of toxic Planktothrix blooms and changes in growth and population dynamics of coregonids, thus providing a possible explanation for the observed decreases in fishery yields. However, despite the existence of a plausible explanation by association and the serendipity of observed events, there is, at present, no information available on the specific sensitivity of coregonids to cyanobacterial blooms and/or cyanobacterial toxins. With respect to the anatomical organisation, the digestive tract of coregonids includes a stomach, pyloric caeca and a short ileum. Thus, coregonids are anatomically very similar to trout, both taxonomically belonging to the order of salmoniformes. However, in contrast to trout, coregonids feed exclusively on plankton. The feeding habits of the adult coregonids therefore resemble more those of the planktivorous cyprinid species rather than those of the predominantly piscivorous salmonids. Consequently, neither carp (cyprinids) nor trout (salmonids) serve as reliable surrogate species to assess the toxicity of Planktothrix blooms in coregonids.

The aim of this study was therefore to investigate the effects of an environmental relevant dose of $P$. rubescens filaments orally applied to coregonids (Coregonus lavaretus L.) and to discuss the findings in the context of toxicity studies with $M$. aeruginosa bloom of freeze-dried material and/or MC-LR in carp and trout.

\section{Materials and methods}

\subsection{Chemicals and reagents}

All chemicals were of the highest analytical grade commercially available. Microcystin-LR (MC-LR) was obtained from Alexis (Switzerland). [D-Asp $\left.{ }^{3}-(E)-\mathrm{Dhb}^{7}\right]$-microcystin$\mathrm{RR}\left(\mathrm{Asp}^{3}-\mathrm{Dhb}^{7}\right.$-MC-RR) was kindly provided by Judith Blom, University of Zurich, Switzerland and [D-Asp ${ }^{3}$ ]-microcystinRR (Asp ${ }^{3}$-MC-RR) by Jussi Meriluoto, Abo Akademi University Turku, Finland.

\subsection{Cultivation, toxin extraction and characterisation of $P$. rubescens}

P. rubescens was originally isolated from a Lake Ammersee seston sample in autumn 2002 and cultivated in BG11 medium according to the method described by Rippka et al., 1979. $P$. rubescens cell density was determined via image processing as described by Ernst et al. (2006). Microcystin-LR equivalent content and microcystin congener composition of $P$. rubescens were characterised via anti-Adda MC-ELISA (Abraxis, USA; see Fischer et al. (2001)), colorimetric phosphatase-inhibition assay (cPPA; see Heresztyn and Nicholson (2001)), and HPLC using extract samples ( $70 \%$ methanolic-followed by solid phase extraction, see Ernst et al. (2005)).

Adda-ELISA and CPPA analyses were carried out on three independent replicates of duplicate samples. MC-LR equivalent content (MC-LR equiv. ) was calculated using an MC-LR standard as reference. HPLC was performed as described by Ernst et al. (2005). Microcystin congeners were characterised using retention time and known typical spectra in comparison with $\mathrm{Asp}^{3}-\mathrm{Dhb}^{7}-\mathrm{MC}-\mathrm{RR}$ and $\mathrm{Asp}^{3}-\mathrm{MC}-\mathrm{RR}$ standards. Quantification of the $\mathrm{Asp}^{3}$-MC-RR variant(s) was achieved using the peak area which was then transformed to express MC-LR equivalent content (MC-LR equiv.). 
Table 1A

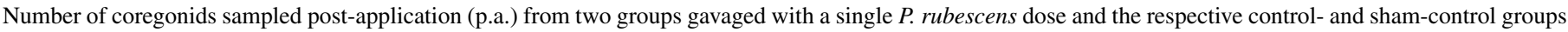
for histological and analytical assessment

\begin{tabular}{|c|c|c|c|c|c|c|c|}
\hline Tank & $n$ & Treatment & Before & 9 h p.a. & 24 h p.a. & 48 h p.a. & 72 h p.a. \\
\hline I & 6 & Control & 3 & & & 3 & \\
\hline II & 6 & Sham-control & & & 3 & & 3 \\
\hline III & 12 & Exposed & & 3 & 3 & 3 & 3 \\
\hline IV & 12 & Exposed & & 3 & 3 & 3 & 3 \\
\hline
\end{tabular}

\subsection{Fish exposure}

One-year-old coregonids (C. lavaretus L.), with an average weight and average length of $9.9 \pm 1.9 \mathrm{~g}$ and $11.4 \pm 0.7 \mathrm{~cm}$, respectively, were obtained from the fisheries administration department Uri, Altdorf, Switzerland. Fish were fed (15\% of body weight daily) with frozen chironomid larvae (Honka, Germany). Coregonids were acclimatised for 1 week prior to $P$. rubescens gavage in 1001 flow-through tanks. Tanks were supplied with tap water and additionally aerated using commercial $5 \mathrm{~W}$ aeration pumps (Tetra, Germany).

Previously described $P$. rubescens cell densities determined in lakes attained up to 150,000 cells/ml (Hoeger et al., 2005). Maximum cell densities determined in Lake Ammersee range up to 80,000 cells/ml (Ernst et al., 2001), Fuentes and Eddy (1997) determined for trout fry an average water uptake of up to $0.5 \mathrm{ml} \mathrm{kg}^{-1} \mathrm{~h}^{-1}$. Assuming a comparable water uptake for coregonids and considering the above mentioned $P$. rubescens cell densities, a fish weighing $10 \mathrm{~g}$ approximately requires 4 and 8 days, respectively, in order to ingest a dose of 80,000 cells. As the described $P$. rubescens blooms/layers usually persist for weeks and months (Ernst et al., 2001; Jacquet et al., 2005), this dose appeared to be environmental relevant and was subsequently applied in the gavage experiment.

After acclimatisation, fish were anaesthetised by $100 \mathrm{mg} / \mathrm{l}$ ethyl 3-aminobenzoate methanesulfonate (MS-222; Fluka, Germany) for gavaging. A single $120 \mu \mathrm{l}$ dose of $P$. rubescens culture, at a density of 80,000 cells per $120 \mu 1$, was applied to 24 coregonids using blunt-tip gavage syringes (Roth, Germany). Six coregonids served as sham-control and received a single dose of $120 \mu \mathrm{l} 0.9 \%$ of $\mathrm{NaCl}$ while an additional six coregonids were used as corresponding control (no gavage). Following gavage, $P$. rubescens gavaged coregonids were placed in two separate tanks (12 fish per tank), control and sham-control fish were placed in separate tanks (6 fish per tank) (Table 1A). Water temperature was measured twice daily. The $95 \%$ confidence interval of the tank temperature was $\left[14-15^{\circ} \mathrm{C}\right]$ and $\left[12-15^{\circ} \mathrm{C}\right]$ in the tanks stocked with exposed and sham-control fish, respectively.

\subsection{Behavioural observations and opercular beat rate}

Fish were observed for behavioural changes daily. The opercular beat rate of sham-control and exposed fish was determined $1 \mathrm{~h}$ before (basal rate) and 1, 3, 19, 25, 29, 46, 54 and $70 \mathrm{~h}$ post-gavage (Table 1B) by counting the opercular movement of four individuals per tank for $15 \mathrm{~s}$ each. The determined opercular counts were adjusted for temperature effect via addition of a correction factor $c\left(c=\left(15^{\circ} \mathrm{C}-\right.\right.$ actual temperature $\left.) \times 0.5\right)$ derived from a normalised opercular rate in the sham-control tank. Adjusted counts were multiplied by four to give an opercular rate per min.

\subsection{Experimental parameters}

Six $P$. rubescens gavaged coregonids were sampled 9, 24, 48 and $72 \mathrm{~h}$ post-application. Three fish of the control group were sampled before and $48 \mathrm{~h}$ post-application, three fish of the shamcontrol 24 and $72 \mathrm{~h}$ post-application as depicted in Table $1 \mathrm{~A}$. The experimental parameters determined during and post-exposure are shown in Table 1B and described below.

Weight: Wet weight of fish was determined on a fine balance (PB3002; Mettler, Germany).

Length: Length was determined from nose-tip to tail using a centimetre ruler and determined to the nearest $\mathrm{mm}$.

Condition factor: Condition was determined using the condition factor: $\mathrm{CF}=$ weight $(\mathrm{g}) \times(\text { length }(\mathrm{mm}))^{-3} \times 10^{5}$ (Barton et al., 2002).

HSI: The hepatosomatic index (HSI) was calculated as HSI=liver weight $(\mathrm{g}) \times 100 \times$ body weight $(\mathrm{g})^{-1}$.

Plasma glucose: Plasma glucose was determined in blood taken from the caudal vein, using a $1 \mathrm{ml}$ syringe and a $0.40 \mathrm{~mm} \times$ $20 \mathrm{~mm}$ needle (Braun, Germany). Whole blood samples were immediately frozen and stored at $-20^{\circ} \mathrm{C}$. Before measurement,

Table 1B

Time-points of parameter determination during the experiment

\begin{tabular}{|c|c|c|c|c|c|c|c|c|c|c|c|}
\hline & -1 & $\begin{array}{cc}+13 \\
+1 \\
+\end{array}$ & 9 & 19 & $\begin{array}{c}2425 \\
+\quad 1\end{array}$ & $\stackrel{29}{+}$ & $\stackrel{46}{+}$ & $\stackrel{48}{4}^{48}$ & $\begin{array}{c}54 \\
+\end{array}$ & & $\stackrel{72}{\longrightarrow}$ \\
\hline beat rate & $\mathrm{x}$ & $\mathrm{x} x$ & & $\mathrm{x}$ & $\mathrm{x}$ & $\mathrm{x}$ & $\mathrm{x}$ & & $\mathrm{x}$ & $\mathrm{x}$ & \\
\hline weight & & & $\mathrm{x}$ & & $\mathrm{x}$ & & & $\mathrm{x}$ & & & $\mathrm{x}$ \\
\hline HSI & & & $\mathrm{x}$ & & $\mathrm{x}$ & & & $\mathrm{x}$ & & & $\mathrm{X}$ \\
\hline condition & & & $\mathrm{x}$ & & $\mathrm{x}$ & & & $\mathrm{x}$ & & & $\mathrm{x}$ \\
\hline plasma glucos & & & $\mathrm{x}$ & & $\mathrm{x}$ & & & $\mathrm{x}$ & & & $\mathrm{x}$ \\
\hline histopathology & & & $\mathrm{x}$ & & $\mathrm{x}$ & & & $\mathrm{x}$ & & & $\mathrm{x}$ \\
\hline immunhistolo & & & $\mathrm{x}$ & & $\mathrm{x}$ & & & $\mathrm{x}$ & & & $\mathrm{x}$ \\
\hline
\end{tabular}


samples were thawed and centrifuged at $16,000 \times g$ for $15 \mathrm{~min}$. Subsequently, plasma glucose was determined by analysing the remaining supernatant using an automatic sensor (Accu-Chek, Roche, USA) according to the manufacturer's instructions. Samples were analysed in triplicate.

Histopathology: Liver, kidney, gill, pylori and hindgut were dissected from each fish, a representative tissue sample placed into a labelled tissue cassette and briefly fixed in 4\% PBSbuffered formalin. Tissues were routinely processed by RCC Ltd. (Itingen, Switzerland), i.e. paraffin embedded, sectioned to 3-5 $\mu \mathrm{m}$, mounted on microscope slides and stained with hematoxylin and eosin (H\&E). Histopathological assessment was carried out by light microscopy at 40-400-fold magnification. Pathological changes were classified as none (0), mild (1), moderate (2), strong (3) and severe (4), including intermediate classes, e.g. $0.5,1.5$, etc.

Immunohistochemical determination of microcystin: Liver, kidney, gill and intestine tissue on polylysin-coated glass slides were deparaffinised in 100\% xylol, rehydrated in descending ethanol concentrations $(100 \%, 95 \%$ and $70 \%)$ and then incubated with $1 \mathrm{mg} / \mathrm{ml}$ type XIV bacterial protease (Sigma-Aldrich, Germany) in PBS for antigen-demasking at $37^{\circ} \mathrm{C}$ for $10 \mathrm{~min}$. Endogenous peroxidase was blocked with $3 \% \mathrm{H}_{2} \mathrm{O}_{2}$ at room temperature for $15 \mathrm{~min}$. Endogenous biotin was blocked using a commercial blocking kit (Avidin/Biotin Blocking Kit, BioGenex, USA). Slides were further blocked with normal goat serum (1:500 in PBS; Vector Laboratories, U.K.) for $20 \mathrm{~min}$ and a casein solution (Power Block ${ }^{\mathrm{TM}}$, BioGenex, USA) for 10 min at room temperature. Adda antiserum (\#824, see Fischer et al. (2001)) was diluted 1:5000 in Power Block ${ }^{\mathrm{TM}}$ and applied to the tissue section in a humidified atmosphere for $16 \mathrm{~h}$ at $4{ }^{\circ} \mathrm{C}$. Antigen-antiserum complexes were visualised using a HRP-labelled, biotin-streptavidin amplified detection system and 3-amino-9-ethylcarbazole (AEC) chromogen (Super Sensitive ${ }^{\mathrm{TM}}$, BioGenex, USA). Sections were counterstained at room temperature for 6 min with Mayer's hematoxylin (Sigma-Aldrich, Germany), rinsed with tap water and mounted using Chrystal/Mount ${ }^{\mathrm{TM}}$ (Biomeda, USA) and Shandon Histomount ${ }^{\mathrm{TM}}$ (Thermo Electron Corporation, Germany). An organ was classified to be MC-positive when MC-positive areas were above background chromogen staining and the positive staining areas were congruently observable in two independently stained serial sections from the same organ sample.

\subsection{Statistical analyses}

As fish were gavaged individually, individuals were considered to represent replicates for statistical purposes. The potential influence of group holding of the respective fish per treatment/sham-control/control group was assumed to be negligible as the influence of group holding should be comparable across groups. As there were no statistical differences between data at the two time-points, data of the control fish were combined and represented as the control cohort (six individuals). Individual data from sham-control fish were combined as already described for the controls. Statistical analyses were carried out using GraphPad Prism $4{ }^{\circledR}$ (USA) Software. Values
Table 2

The opercular beat rate determined in coregonids before the gavage procedure (basal rate, before application (b.a.)) and comparison of beat rates determined for sham-control coregonids and coregonids, exposed to a single dose of $P$. rubescens at various time-points post-application (p.a.)

\begin{tabular}{lll}
\hline $\begin{array}{l}\text { Time to application } \\
\text { (h p.a.) }\end{array}$ & Sham-control (beat/min) & Exposed (beat/min) \\
\hline 1 & $109 \pm 7(4)$ & $134 \pm 12(8)^{* *}$ \\
3 & $103 \pm 2(4)$ & $117 \pm 11(8)^{* *}$ \\
19 & $94 \pm 4(4)$ & $115 \pm 12(8)^{* *}$ \\
25 & $107 \pm 6(3)$ & $108 \pm 7(8)$ \\
29 & $117 \pm 8(3)$ & $117 \pm 6(8)$ \\
46 & $95 \pm 4(3)$ & $103 \pm 6(8)$ \\
54 & $115 \pm 5(3)$ & $116 \pm 15(6)$ \\
70 & $109 \pm 12(3)$ & $114 \pm 9(6)$ \\
\hline
\end{tabular}

When time to application is $1 \mathrm{~h}$ b.a. the basal rate is $107 \pm 10$ beat/min (12). Values are given as mean \pm S.D.; the number of fish observed is given in parentheses; significant differences between sham-control and exposed fish are indicated $\left({ }^{* *} p<0.01\right)$.

were given as the mean \pm standard deviation (S.D.) of at least three individuals for opercular beat rate determinations and of at least five individuals for weight, HSI, condition factor and serum glucose analyses.

Opercular beat rate: Statistical differences in opercular beat rates were analysed using a one-way ANOVA followed by Bonferroni's multiple comparison test to compare beat rates of the multiple time-points of the sham-control fish (Table 2) and the rates of the 12 individuals (4 fish per tank) assessed before gavage (basal rate, see Tables $1 \mathrm{~B}$ and 2). An $F$-test for determination of homogeneity of variances followed by an unpaired $t$-test (twotailed) with Welch's correction was employed to compare the opercular beat rates observed in the sham-control with those of the $P$. rubescens gavaged fish at each time-point of the experiment.

Condition factor: Condition factors were tested for statistical differences using a $F$-test to determine homogeneity of variances followed by an unpaired $t$-test (two-tailed) to compare the condition factor determined in sham-control with those of the control fish. A Bartlett's test and one-way ANOVA followed by a Dunnett's post-test were employed to compare the multiple timepoints of the $P$. rubescens gavaged fish with the sham-control fish cohort.

Plasma glucose: Glucose levels were tested for statistical differences using a $F$-test to determine homogeneity of variances followed by an unpaired $t$-test (two-tailed) to compare the plasma glucose concentration determined in sham-control with those determined in the control fish. A Bartlett's test and oneway ANOVA followed by a Dunnett's post-test were employed to compare the multiple time-points of the $P$. rubescens gavaged fish with the combined sham-control fish.

Histopathology: Pathological changes in the respective tissues are given as median \pm mean absolute deviation (MAD) of the individual ranks of at least four examined individuals. Ranking of pathological changes was tested for statistical differences using the non-parametric Mann-Whitney $U$-test.

Significant differences were determined at the ${ }^{* *} p<0.01$ and ${ }^{*} p<0.05$ level for all statistical analyses. 
Table 3

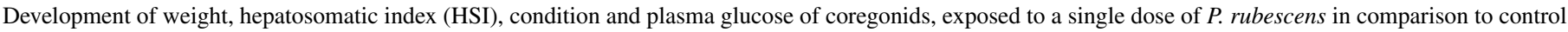
fish for each time-point post-application (p.a.)

\begin{tabular}{|c|c|c|c|c|c|c|}
\hline \multirow[t]{2}{*}{ Treatment } & \multirow[t]{2}{*}{ Control } & \multirow[t]{2}{*}{ Sham-control } & \multicolumn{4}{|l|}{ Exposed } \\
\hline & & & 9 h p.a. & 24 h p.a. & 48 h p.a. & 72 h p.a. \\
\hline Mean weight (g) & $9.1 \pm 3.45(6)$ & $9.6 \pm 1.33(5)$ & $10.1 \pm 2.10(6)$ & $10.0 \pm 1.77(6)$ & $9.0 \pm 3.01(6)$ & $9.4 \pm 1.26(5)$ \\
\hline HSI (mg/g) & $1.17 \pm 0.205(5)$ & $1.09 \pm 0.178(6)$ & $1.11 \pm 0.156(5)$ & $1.11 \pm 0.081(6)$ & $1.06 \pm 0.104(6)$ & $1.19 \pm 0.153(5)$ \\
\hline Condition factor & $0.73 \pm 0.030(6)$ & $0.73 \pm 0.065(5)$ & $0.69 \pm 0.055(6)$ & $0.70 \pm 0.071(6)$ & $0.67 \pm 0.133(6)$ & $0.65 \pm 0.070$ \\
\hline Plasma glucose $(\mathrm{mg} / 100 \mathrm{ml})$ & $15.6 \pm 05.95(6)$ & $31.2 \pm 08.40(5)$ & $54.1 \pm 27.08(6)$ & $43.3 \pm 48.62(5)$ & $17.4 \pm 04.35(6)$ & $30.5 \pm 14.38(6)$ \\
\hline
\end{tabular}

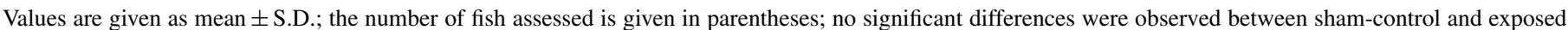
fish at the $p<0.05$ level.

\section{Results}

\subsection{P. rubescens characterisation}

The administered $P$. rubescens culture was shown to contain $2.1 \pm 0.03 \mu \mathrm{g}$ MC-LR equiv. $/ \mathrm{mg}$ d.w. and $3.3 \pm 0.26 \mu \mathrm{g} \mathrm{MC}-$ $\mathrm{LR}_{\text {equiv. }} / \mathrm{mg}$ via HPLC and Adda-ELISA analysis, respectively. Toxin quantification via the colorimetric PP-inhibition assay (cPPA) suggested that the $P$. rubescens culture extract contained $0.03 \pm 0.02 \mu \mathrm{g}$ MC-LR equiv. $/ \mathrm{mg}$ and thus less than that determined via either HPLC or Adda-ELISA. More in-depth HPLC analysis demonstrated one broad main peak with a shoulder and retention time and spectrum comparable to an overlay of the $\mathrm{Asp}^{3}$-Dhb ${ }^{7}$-MC-RR and $\mathrm{Asp}^{3}$-MC-RR peaks. In addition, further analysis of retention times and spectra of supplementary peaks observed, suggested the presence of anabaenopeptines and cyanpeptolines in the $P$. rubescens culture extract (data not shown).

\subsection{Fish exposure (behavioural observations and opercular beat rate)}

Following gavage and subsequent reanimation from MS-222 only very few of the gavaged fish were observed to regurgitate a small amount of the $P$. rubescens suspension through the gill. Three treated fish died during anaesthesia and were replaced immediately with additional fish. With the exception of the anaesthesia-related mortality, no further mortalities were observed subsequent to anaesthesia and reanimation.

Three hours post-application, the exposed fish appeared more susceptible to startling and swimming behaviour was more hectic than observed in the corresponding sham-control fish. These behavioural differences, however, decreased and became indiscernible from the behavioural patterns of the sham-control fish with increasing duration of the experiment.

A significantly elevated opercular beat rate was observed at the $1 \mathrm{~h}$ post-application (p.a.) time-point in the $P$. rubescens culture exposed fish when compared to the corresponding shamcontrol fish. This increased opercular beat rate was also significantly elevated at 3 and $19 \mathrm{~h}$ p.a. (Table 2), however, the large variation of the individual data at the respective time-points suggests that the significant effects at the 3 and $19 \mathrm{~h}$ time-points p.a., although mathematically correct, may not be of biological relevance as the data lie within the range of the normal opercular beat rates of the sham-control fish. No differences were observed between the opercular beat rate of the sham-control fish and the basal rate determined prior to the start of the experiment.

\subsection{Weight, HSI, condition factor and plasma glucose}

No significant differences in weight or HSI were observed between treatment and control groups (Table 3). The condition factors determined in the $P$. rubescens culture exposed fish appeared lower than those of the corresponding controls and also appeared to decrease with increasing experiment time. This trend was, however, not statistically significant.

Plasma glucose levels were not significantly different between treatment and the sham-control group (Table 3). $P$. rubescens exposure, however, appeared to increase the variability of the glucose levels determined. This was confirmed by statistically different variances as demonstrated by Bartlett's test analysis. This high variability was probably due to the low number of individuals used, and may thus have prevented detection of statistically significant differences between exposed and sham-control fish. Handling of the fish clearly increased stress and consequently plasma glucose levels (Table 3 ), as evidenced by the differences between the control and the sham-control fish.

\subsection{Histopathological changes}

Liver: Neither control nor sham-control fish presented with histopathological changes in the livers beyond the normal range observed in coregonids of this age group. In contrast, $P$. rubescens gavaged fish presented with an time-dependent increase in liver pathology which consisted of focal hepatocytes with granulated cytosol, focal disintegration of the parenchymal liver architecture, cell dissociation, chromatin margination, diffuse focal necrosis and apoptosis, necrosis peripheral to central veins, ruptured vessels, dilated sinusoids, infiltrations of mononuclear cells and coagulative necrosis peripheral to central veins (Fig. 1). The degree of pathological change observed in $P$. rubescens gavaged fish was significantly different from the corresponding controls at 24,48 and $72 \mathrm{~h}$ p.a. (Table 4).

Kidney: Sporadic changes in the renal tubules of control and exposed fish were characterised by the occurrence of low frequencies of apoptotic cells, regenerating cells and epithelial cell exfoliation. In distinction to corresponding controls, kidneys 


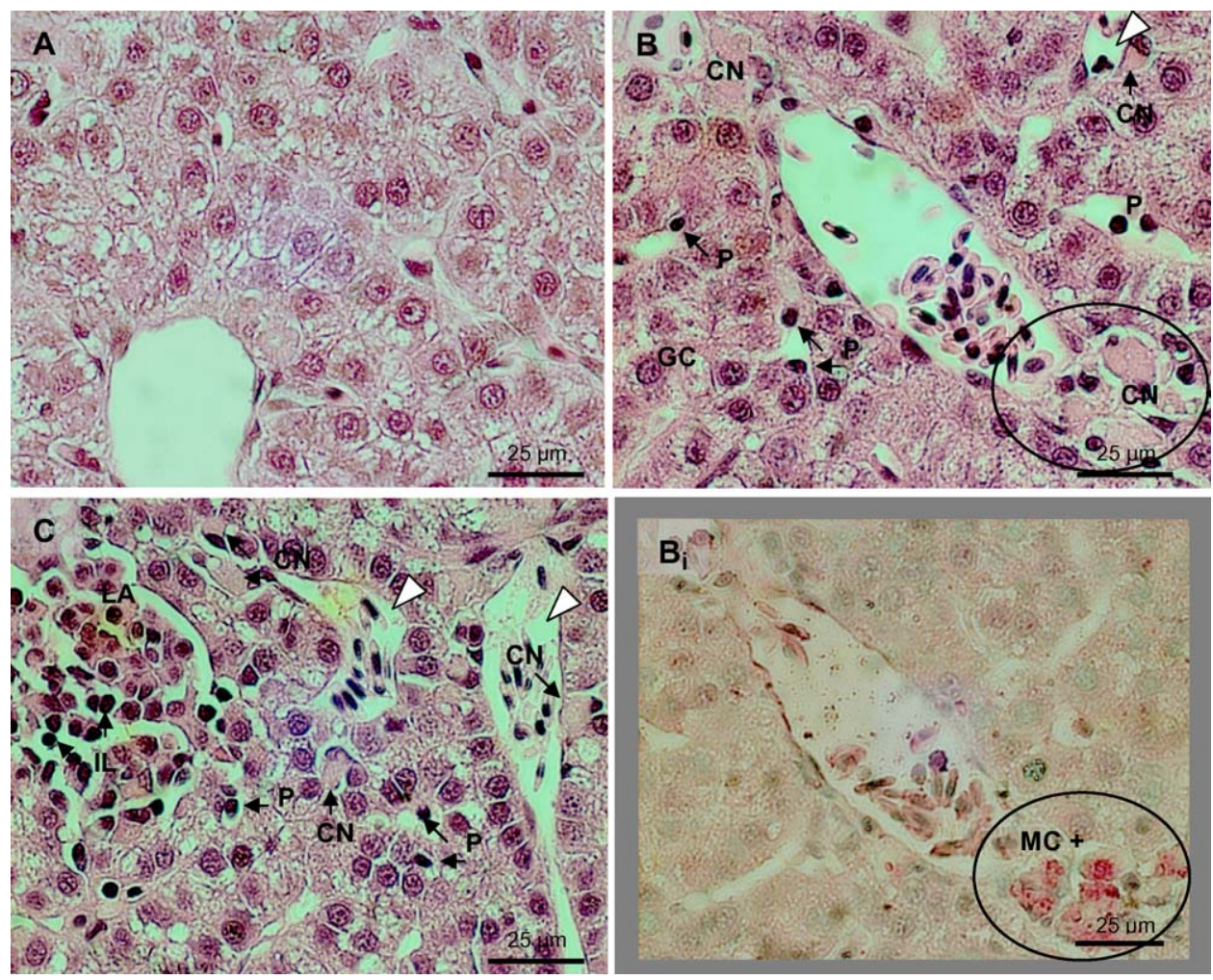

Fig. 1. Liver tissue of control (A) and exposed coregonids $24 \mathrm{~h}(\mathrm{~B})$ and $48 \mathrm{~h}(\mathrm{C})$ post-application. Sections (A-C) stained with $\mathrm{H} \& \mathrm{E}$ or microcystin antibodies $\left(\mathrm{B}_{\mathrm{i}}\right)$. Exposed fish presented with dilated sinusoids (white arrows), a partial loss of liver architecture (LA), infiltration of leucocytes (IL), granulation of hepatocyte cytosol $(\mathrm{GC})$, pyknosis $(\mathrm{P})$ and coagulative necrosis $(\mathrm{CN})$. Comparison of $\mathrm{H} \& \mathrm{E}$ and immunostained sections $\left(\mathrm{B}\right.$ and $\mathrm{B}_{\mathrm{i}}$ ) demonstrate the presence of microcystin (MC+) in histologically changed tissue sections (circle).

of $P$. rubescens gavaged fish presented with enhanced tubular degeneration which included vacuolisation and cell shedding, proteinaceous casts and calcium-phosphate-precipitates in the tubular lumina (Fig. 2). In addition, coagulative necrosis was observed in the interstitium. However, the degree of pathological change observed in $P$. rubescens gavaged fish was not significantly different from the corresponding controls (Table 4).

Pylori and hindgut: Pylori and hindgut of control and shamcontrol fish were unremarkable. In contrast, distinct histopathological changes were observed in exposed coregonids. Characteristic were mild epithelial degeneration in the pylori, and loss of the mucosa structure, frayed gut villi, exfoliation of epithelial cells, widespread cell lysis, infiltration of leucocytes and intraluminal protein cast deposition in the hindgut (Fig. 3). The pathological changes appeared to be most predominant at the $24 \mathrm{~h}$ p.a. time-point and then decreased to background at $72 \mathrm{~h}$ p.a. This observation was also apparent from the degree of pathological change classifications, with the $24 \mathrm{~h}$ p.a. time-point pathological changes being significantly higher than those of the sham-control for both the pylori and the hindgut (Table 4).

Gills: Pathological changes attributable to P. rubescens gavage were not unequivocal discernible from changes (vacuolisation, sporadic lamellar tip clubbing) observed in the control fish. This is also corroborated by the observation that no signif-

Table 4

Histopathological changes observed in various organs of $P$. rubescens exposed fish compared to control- and sham-control fish

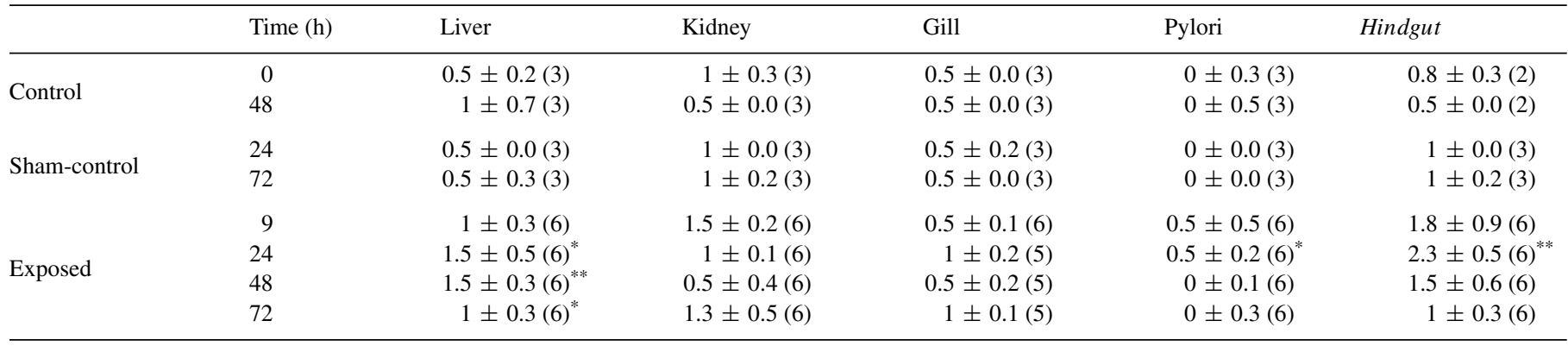

Histopathological changes were ranked from none (0) to severe (4) including intermediate classes, e.g. 0.5, 1.5, etc. Values are presented as median \pm mean absolute deviation for each time point; the number of fish assessed is given in parentheses. For statistical analysis individuals of the control groups were summed to one control- and one sham-control cohort. Significant differences between sham-control and exposed fish are indicated $\left({ }^{*} p<0.05\right.$ and $\left.{ }^{* *} p<0.01\right)$. 

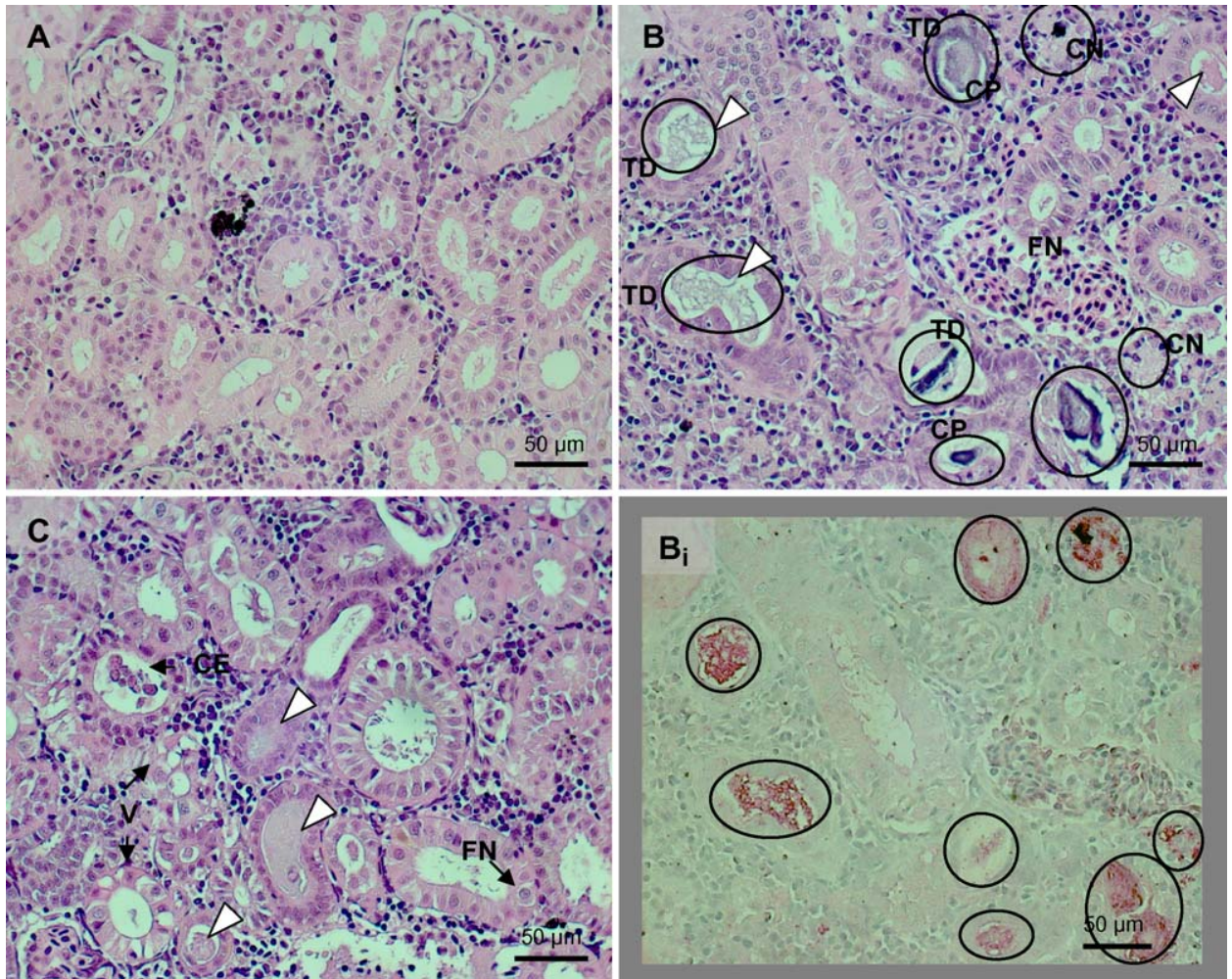

Fig. 2. Kidney tissue of control (A) and exposed coregonids $9 \mathrm{~h}(\mathrm{~B})$ and $72 \mathrm{~h}(\mathrm{C})$ post-application. Sections (A-C) stained with H\&E or microcystin antibodies $\left(\mathrm{B}_{\mathrm{i}}\right)$. Exposed fish presented with focal (FN) and coagulative (CN) interstitial necrosis in kidney, as well as a degeneration of the tubular lining (TD), including vacuolation (V) and exfoliation (CE) of tubular epithelial cells into the tubular lumen, proteinaceous casts (white arrows) and calcium phosphate precipitates (CP). Comparison of $\mathrm{H} \& \mathrm{E}$ and immunostained sections (B and $\mathrm{B}_{\mathrm{i}}$ ) demonstrates the presence of microcystin ( $\mathrm{MC}+$ ) in histologically changed tissue sections (circles).
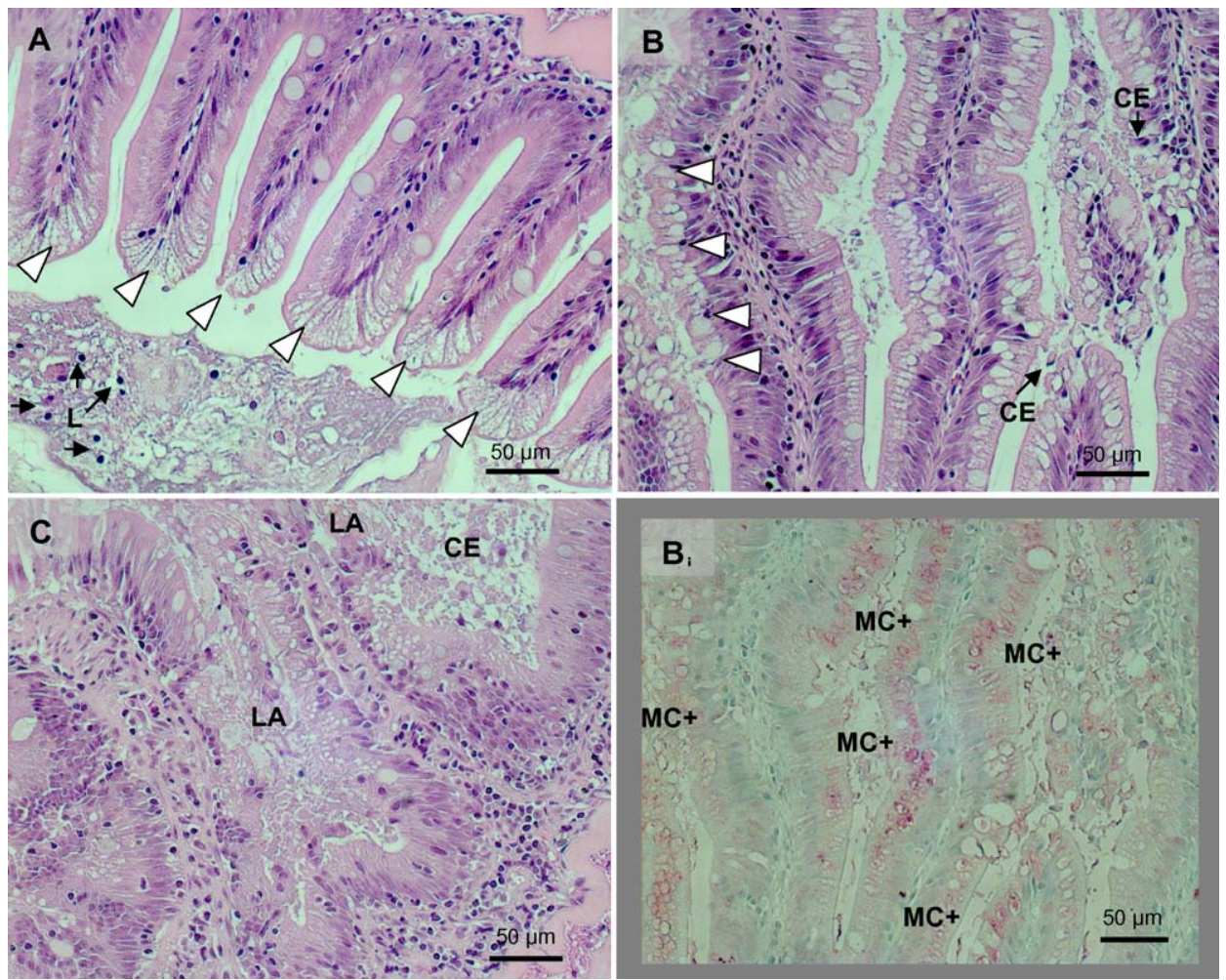

Fig. 3. Pylori (A) and hindgut tissue (B and C) of exposed coregonids $24 \mathrm{~h}$ post-application. Sections (A-C) stained with H\&E or microcystin antibodies ( $\mathrm{B}_{\mathrm{i}}$ ). Exposed fish presented with epithelial degeneration and cell lysis (white arrows), exfoliation of epithelial cells lumen (CE), presence of leucocytes (L) and loss of the gut architecture (LA). Comparison of $\mathrm{H} \& \mathrm{E}$ and immunostained sections (B and $\mathrm{B}_{\mathrm{i}}$ ) demonstrate the presence of microcystin $(\mathrm{MC}+)$ in affected gut regions. 
icant differences were observed in overall pathological scores between gills of P. rubescens gavaged and control fish (Table 4).

\subsection{Microcystin-immunohisto chemistry}

MC-positive staining was most distinct in the liver of the exposed fish, with both the number of positive fish and the area of positive staining being highest at the $24 \mathrm{~h}$ p.a. time-point. MC-positive staining could also be demonstrated in foci with coagulative necrosis and disrupted vessels (Fig. 1).

Kidney tissues were variable with regard to positive MCstaining, which occurred most frequently in fish of the 9 and $72 \mathrm{~h}$ time-points and less frequently in fish of the 24 and $48 \mathrm{~h}$ p.a. time-point. However, immunopositive staining was primarily observable in kidneys with obvious pathology, i.e. overt interstitial and epithelial necrosis and proteinaceous casts (Fig. 2).

Immunopositive staining was also detectable in the pylori and hindgut of $P$. rubescens gavaged fish at 9 and $24 \mathrm{~h}$ p.a. MC-staining was primarily observed in the mucosal epithelium, while in the pylori this was restricted to the villi tips (Fig. 3).

\section{Discussion}

\subsection{P. rubescens characterisation}

The administered $P$. rubescens culture was shown to contain microcystin corresponding to an amount of 2.1 and $3.3 \mu \mathrm{g}$

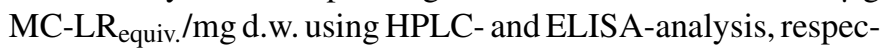
tively. Differences between ELISA and HPLC assessment are in accordance to those published in other studies (Rapala et al., 2002; Hawkins et al., 2005). The differences between the quantities determined by ELISA and HPLC and those determined via the cPPA are in accordance to observations previously described by Rapala et al. (2002), who demonstrated that cPPA data achieved with extracts of MC-producing Planktothrix strains returned only 5\% of the values obtained by ELISA and HPLC. The quantities of microcystin congeners determined via ELISA and HPLC were therefore considered more reliable than those determined via the cPPA assay.

HPLC results suggested the main microcystin congener(s) present in the $P$. rubescens extract to be $\mathrm{Asp}^{3}$-MC-RR variant(s). This observation concurs with previous studies, describing demethylated variants of MC-RR to be the predominant MC-congeners in cyanobacteria of the $P$. agardhii/rubescens group in European lakes (Luukkainen et al., 1993; Fastner et al., 1999a; Blom et al., 2001; Ernst et al., 2001; Spoof et al., 2003; Kurmayer et al., 2005; Jacquet et al., 2005). MC-quantities detected in $P$. agardhii/rubescens range from 0.3 to $6 \mu \mathrm{g} / \mathrm{mg}$ d.w. (Fastner et al., 1999b; Ernst et al., 2001; Kurmayer et al., 2005). The MC-composition and quantities found for the lake Ammersee $P$. rubescens used for coregonid gavaging are comparable to those typically described for $P$. agardhiilrubescens in European lakes.

Assuming an average filament-length of 231.9 cells per filament (derived from filament measurements in Lake Ammersee over a 1 year period, Ernst (2000)), an average weight of
$8 \mu \mathrm{g} / 1000$ filaments (Gammeter et al., 1997) and based on MCquantities determined by HPLC and ELISA, the 80.000 cells applied per fish $(9.9 \pm 1.9 \mathrm{~g})$ corresponded to a single dose of 0.6-0.9 $\mu \mathrm{g} \mathrm{MC-LR}$ equiv. $/ \mathrm{kg}$ b.w. (0.3 mg P. rubescens d.w. $/ \mathrm{kg}$ b.w.).

\subsection{Behavioural observations and opercular beat rate}

As already observed in earlier studies with other fish species (Tencalla and Dietrich, 1997; Snyder et al., 2002), a few of the coregonids were able to regurgitate and expel parts of the gavaged cyanobacteria through the gills. Since the regurgitated amounts appeared to be minimal, gavage was considered successful. The observed regurgitation, however, suggests that coregonids aim to actively avoid uptake of $P$. rubescens. That $P$. rubescens represents a stressor to coregonids can be inferred from the behavioural changes, including hectic swimming and an increased ventilation as indicated by the significantly elevated opercular beat rate, observed in coregonids $1 \mathrm{~h}$ post-gavage. Increased ventilation rates were also reported by Carbis et al. (1996) and Kotak et al. (1996) irrespective of whether the MCexposure was via the oral or intraperitoneal route. While in the study described by Carbis et al. (1996) the higher ventilation rate in carp treated with MC-LR was possibly attributable to simultaneously occurring gill damage, no gill patholology was observed in the current coregonid study. Therefore, the elevated ventilation observed in the gavaged coregonids appear more likely to result from stress induced by gastrointestinal $P$. rubescens than by gill damage.

\subsection{Weight, HSI, condition factor and plasma glucose}

Although no significant effects of $P$. rubescens exposure were observed on weight, HSI or condition factor, stress related effects were observable using plasma glucose levels as the end-point. Indeed, handling of fish per se increased plasma glucose levels (mobilisation of glycogen stores) as already demonstrated in carp by Svobodová et al. (1999), i.e. levels in sham-control fish were approximately double the basal levels of non-handled control fish. $P$. rubescens treatment increased this basal plasma glucose level by approximately three- to four-fold in the period 9-24h p.a., supporting the above observation that ingested $P$. rubescens provides for an increased stress to coregonids. Whether the increased plasma glucose levels are solely related to a catecholamine- and cortisol stimulated mobilisation of energy and thus stress-mediated higher energy demand (Bury et al., 1996; Barton et al., 2002) or also as a consequence of a disruption glycogen homeostasis resulting from protein phosphatase inhibition as suggested by Råbergh et al. (1991) and Malbrouck et al. (2004), cannot be clearly deduced from the data presented here. However, the influence of the toxinmediated protein phosphatase inhibition appears secondary, as plasma glucose levels appear to return to at least control levels within $48 \mathrm{~h}$ p.a., while an extended exposure to toxins ( $P$. rubescens) via the gastrointestinal would be expected to result in an appreciable and continued elevation of plasma glucose levels. 


\subsection{Histopathology and immunohistochemistry}

The above interpretation is further corroborated by the observation that the earliest time-point with significantly enhanced liver pathology and immunohistochemically defined presence of MC was between 24 and $48 \mathrm{~h}$ p.a., a time-frame where plasma glucose levels appeared to be declining back to control levels. Consequently the stress, as depicted by plasma glucose levels, does not appear to be associated with, or a consequence of, liver pathology. Evidence for a prolonged exposure to toxins is provided by the observation that increased gastrointestinal pathology was observed up to $48 \mathrm{~h}$ p.a. and this then gradually declined to control levels, while a slightly delayed onset of pathology was observed in the liver. The described pathological changes in the gastrointestinal tract, liver and kidney are characteristic of pathological lesions described earlier for microcystin intoxications (Råbergh et al., 1991; Rodger et al., 1994; Tencalla et al., 1994; Carbis et al., 1996; Kotak et al., 1996; Tencalla and Dietrich, 1997; Fischer et al., 2000; Fischer and Dietrich, 2000; Fournie and Courtney, 2002; Malbrouck et al., 2003). The combined data of pathology and MC-immunohistochemistry suggest MC uptake and accumulation to be highest $24 \mathrm{~h}$ post-application, which appears slightly slower than what was observed for trout and carp (Fischer et al., 2000; Fischer and Dietrich, 2000). However, due to the use of non-acutely lethal doses of $P$. rubescens material in this coregonid study, the direct comparison with previous trout and carp studies (Råbergh et al., 1991; Tencalla et al., 1994; Carbis et al., 1996; Fischer et al., 2000; Fischer and Dietrich, 2000) is tentative at best. Indeed, while Fischer et al. (2000) demonstrated a continuum of increasing pathological alteration and MC-immunostaining in the liver of exposed trout and carp, the dose of $P$. rubescens employed in this study resulted in a maximal effect at $24-48 \mathrm{~h} \mathrm{p}$.a. and a regeneration as well as a reduction of immunostaining thereafter. Of importance, however, is the observation that a high number of pathological changes, whether observed in the liver, kidney or gastrointestinal tract, were also immunopositive for MC, suggesting a causal relationship of tissue damage with presence of microcystins as also indicated for other fish species, i.e. trout and carp (Fischer et al., 2000; Fischer and Dietrich, 2000).

The present low-dose exposure experiment in coregonids also suggests that subchronic and chronic exposure to low doses of $P$. rubescens can cause enhanced physiological stress as well as continued pathological changes in the gastrointestinal tract, liver and kidneys possibly leading to decreased functionality of these organs. The combination of stress and organ damage might thus explain the reduced weight and hence fitness observed in coregonids subjected to stratified and dispersed $P$. rubescens blooms such as those occurring in lake Ammersee.

\section{Acknowledgements}

We would like to thank Jussi Meriluoto, Abo Akademi University Turku, Finland and Judith Blom, University Zurich, Switzerland for providing microcystin standards. Helmut Segner, University of Bern, Switzerland, Christoph Kueng, Fish and Wildlife Service Canton Bern and H. Zieri, Fish and Wildlife
Service Canton Uri, Switzerland for the assistance in obtaining sufficient numbers of one-year-old coregonids. RCC Ltd. for histological tissue processing and substantial support. Iris Töpfer for experimental assistance. We would also like to acknowledge the Arthur and Aenne Feindt Foundation (Germany) for kindly funding this study.

\section{References}

Barton, B.A., Morgan, J.D., Vijayan, M.M., 2002. Physiological and condition-related indicators of environmental stress in fish. In: Adams, S.M. (Ed.), Biological indicators of aquatic ecosystem stress. American Society of Fisheries, Bethesda, MD, pp. 111-148.

Berg, K., Skulberg, O.M., Skulberg, R., Underdal, B., Willen, T., 1986. Observations on toxic blue-green algae (cyanobacteria) in some Scandinavian lakes. Acta Vet. Scand. 27, 440-452.

Blom, J.F., Bister, B., Bischoff, D., Nicholson, G., Jung, G., Süssmuth, R.D., Jüttner, F., 2003. Oscillapeptin J, a grazer toxin of the freshwater cyanobacterium Planktothrix rubescens. J. Nat. Prod. 66, 431-434.

Blom, J.F., Robinson, J.A., Jüttner, F., 2001. High grazer toxicity of [D$\left.\operatorname{Asp}^{3}(E)-\mathrm{Dhb}^{7}\right]$ microcystin-RR of Planktothrix rubescens as compared to different microcystins. Toxicon 39, 1923-1932.

Braun, R., 1953. Vom "Burgunderblut". Naturkundliche Skizze, 12 pp.

Briand, J.F., Jacquet, S., Bernard, C., Humbert, J.F., 2003. Health hazards for terrestrial vertebrates from toxic cyanobacteria in surface water ecosystems. Vet. Res. 34, 361-377.

Bury, N.R., Eddy, F.B., Codd, G.A., 1996. Stress responses of brown trout, Salmo Trutta L., to the cyanobacterium, Microcystis aeruginosa. Env. Toxicol. Water Qual. 11, 187-193.

Bury, N.R., Newland, A.D., Eddy, F.B., Codd, G.A., 1998. In vivo and in vitro intestinal transport of ${ }^{3} \mathrm{H}$-microcystin-LR, a cyanobacterial toxin in rainbow trout (Oncorhynchus mykiss). Aquat. Toxicol. 41, 139-148.

Carbis, C., Rawlin, G., Mitchell, G., Anderson, J., McCauley, I., 1996. The histopathology of carp, Cyprinus carpio L., exposed to microcystin by gavage, immersion and intraperitoneal administration. J. Fish Dis. 19, 199-207.

Davis, P.A., Dent, M., Parker, J., Reynolds, J., Walsby, A.E., 2003. The annual cycle of growth rate and biomass change in Planktothrix spp. in Blelham Tarn English Lake District. Freshw. Biol. 48, 852-867.

Dietrich, D.R., Fischer, A., Michel, C., Hoeger, S.J., in press. Toxin mixture in cyanobacterial blooms - a critical comparison of reality with current procedures employed in human health risk assessment. Springer-Verlag, New York.

Ernst, B., 2000. Das Microcystin-haltige Cyanobakterium Planktothrix agardhii und seine Auswirkungen auf die Coregonen im Ammersee. Diploma Thesis. University of Konstanz, Konstanz, 104 pp.

Ernst, B., Dietz, L., Hoeger, S.J., Dietrich, D.R., 2005. Recovery of MC-LR in fish liver tissue. Environ. Toxicol. 20, 449-458.

Ernst, B., Hitzfeld, B.C., Dietrich, D.R., 2001. Presence of Planktothrix sp. and cyanobacterial toxins in Lake Ammersee Germany and their impact on whitefish (Coregonus lavaretus L.). Environ. Toxicol. 16, 483-488.

Ernst, B., Neser, S., O’Brien, E., Hoeger, S.J., Dietrich, D.R., 2006. Determination of the filamentous cyanobacteria Planktothrix rubescens in environmental water samples using an image processing system. Harmful Algae 5, 189-281.

Fastner, J., Erhard, M., Carmichael, W.W., Sun, F., Rinehart, K.L., Rönicke, H., Chorus, I., 1999a. Characterization and diversity of microcystins in natural blooms and strains of the genera Microcystis and Planktothrix from German freshwater. Arch. Hydrobiol. 145, 147-163.

Fastner, J., Neumann, U., Wirsing, B., Weckesser, J., Wiedner, C., Nixdorf, B., Chorus, I., 1999b. Microcystins (hepatotoxic heptapeptides) in German fresh water bodies. Environ. Toxicol. 14, 13-22.

Fischer, W., Hitzfeld, B.C., Tencalla, F., Eriksson, J.E., Mikhailov, A., Dietrich, D.R., 2000. Microcystin-LR toxicodynamics, induced pathology, and immunhistochemical localisation in livers of blue-green algae exposed rainbow trout (Oncorhynchus mykiss). Toxicol. Sci. 54, 365-373. 
Fischer, W.J., Dietrich, D.R., 2000. Pathological and biochemical characterisation of microcystin-induced hepatopancreas and kidney damage in carp. Toxicol. Appl. Pharmacol. 164, 73-81.

Fischer, W.J., Garthwaite, I., Miles, C.O., Ross, K.M., Aggen, J.B., Chamberlin, A.R., Towers, N.R., Dietrich, D.R., 2001. Congener-independent immunoassay for microcystins and nodularins. Environ. Sci. Technol. 35, 4753-4757.

Fournie, J.W., Courtney, L.A., 2002. Histopathological evidence of regeneration following hepatotoxic effects of the cyanotoxin microcystin-LR in the Hardhead Catfish and Gulf Killfish. J. Aquat. Anim. Health 14, 273-280.

Fuentes, J., Eddy, F.B., 1997. Drinking in marine, euryhaline and freshwater teleost fish. In: Hazon, N., Eddy, F.B., Flik, G. (Eds.), Ionic Regulation in Animals. Springer, Berlin, pp. 135-149.

Gammeter, S., Forster, U., Zimmermann, U., 1997. Limnologische Untersuchungen im Zürichsee 1972-1996. Wasserversorgung Zürich (WVZ), Zürich.

Hawkins, P.R., Novic, S., Cox, P., Neilan, B.A., Burns, B.P., Shaw, G., Wickramasinghe, W., Peerapornpisal, Y., Ruangyuttikarn, W., Itayama, T., Saitou, T., Mizuochi, M., Inamori, Y., 2005. A review of analytical methods for assessing the public health risk from microcystin in the aquatic environment. J. Water Supply: Res. Technol. 54, 509-518.

Henriksen, P., 2001. Toxic freshwater cyanobacteria in Denmark. In: Chorus, I. (Ed.), Cyanotoxins. Springer-Verlag, Berlin, pp. 49-56.

Heresztyn, T., Nicholson, B.C., 2001. Determination of cyanobacterial hepatotoxins directly in water using a protein phosphatase inhibition assay. Water Res. 35, 3049-3056.

Hitzfeld, B.C., Hoeger, S.J., Dietrich, D.R., 2000. Cyanobacterial toxins: removal during drinking water treatment, and human risk assessment. Environ. Health Perspect. 108 (Suppl 1), 113-122.

Hoeger, S.J., Hitzfeld, B.C., Dietrich, D.R., 2005. Occurrence and elimination of cyanobacterial toxins in drinking water treatment plants. Toxicol. Appl. Pharmacol. 203, 231-242.

Jacquet, S., Briand, J.F., Leboulanger, C., Avois-Jacquet, C., Oberhaus, L., Tassin, B., Vincon-Leite, B., Paolini, G., Druart, J.C., Anneville, O., Humbert, J.F., 2005. The proliferation of the toxic cyanobacterium Planktothrix rubescens following restoration of the largest natural French lake (Lac du Bourget). Harmful Algae 4, 651-672.

Jewel, M.A.S., Affan, M.A., Khan, S., 2003. Fish mortality due to cyanobacterial bloom in an aquaculture pond in Bangladesh. Pakistan J. Biol. Sci. 6, 1046-1050.

Keil, C., Forchert, A., Fastner, J., Szewzyk, U., Rotard, W., Chorus, I., Krätke, R., 2002. Toxicity and microcystin content of extracts from a Planktothrix bloom and two laboratory strains. Water Res. 36, 2133-2139.

Kotak, B.G., Semalulu, S., Fritz, D.L., Prepas, E.E., Hrudey, S.E., Coppock, R.W., 1996. Hepatic and renal pathology of intraperitoneally administered microcystin-LR in rainbow trout (Oncorhynchus mykiss). Toxicon $34,517-525$

Krupa, D., Czernas, K., 2003. Mass appearance of cyanobacterium Planktothrix rubescens in Lake Piaseczno, Poland. Water Qual. Res. J. Can. $38,141-152$.

Kurmayer, R., Christiansen, G., Gumpenberger, M., Fastner, J., 2005. Genetic identification of microcystin ecotypes in toxic cyanobacteria of the genus Planktothrix. Microbiology 151, 1525-1533.

Lindholm, T., Degerlund, M., Spoof, L., Meriluoto, J., 2002. A century of water quality changes in a coastal lake with toxic Planktothrix. Verh. Internat. Verein. Limnol. 28, 984-987.

Luukkainen, R., Sivonen, K., Namikoshi, M., Fardig, M., Rinehart, K.L., Niemela, S.I., 1993. Isolation and identification of eight microcystins from thirteen Oscillatoria agardhii strains and structure of a new microcystin. Appl. Environ. Microbiol. 59, 2204-2209.

Malbrouck, C., Trausch, G., Devos, P., Kestemont, P., 2003. Hepatic accumulation and effects of microcystin-LR on juvenile goldfish Carassius auratus L. Comp. Biochem. Physiol. 135, 39-48.

Malbrouck, C., Trausch, G., Devos, P., Kestemont, P., 2004. Effect of microcystin-LR on protein phosphatase activity and glycogen content in isolated hepatocytes of fed and fasted juvenile goldfish Carassius auratus L. Toxicon 44, 927-932.

Malbrouck, C., Kestemont, P., 2006. Effects of microcystin on fish. Environ. Toxicol. Chem. 25, 72-86.

Mez, K., 1998. Erste Untersuchungen über toxische Cyanobakterien in Schweizer Mittelland- und Voralpenseen. Institut für Pflanzenbiologie/Mikrobiologie, Zürich, p. 39.

Morabito, G., Ruggiu, D., Panzani, P., 2002. Recent dynamics (1995-1999) of the phytoplankton assemblages in Lago Maggiore as a basic tool for defining association patterns in the Italian deep lakes. J. Limnol. 61 , $129-145$.

Råbergh, C.M.I., Bylund, G., Eriksson, J.E., 1991. Histopathological effects of microcystin-LR, a cyclic peptide toxin from the cyanobacterium (bluegreen alga) Microcystis aeruginosa, on common carp (Cyprinus carpio L.). Aquat. Toxicol. 20, 131-146.

Rapala, J., Erkomaa, K., Kukkonen, J., Sivonen, K., Lathi, K., 2002. Detection of microcystins with protein phosphatase inhibition assay, high performance liquid chromatography-UV detection and enzyme-linked immunosorbant assay: comparison of methods. Anal. Chim. Acta 466, 213-231.

Rippka, R., Deruelles, J., Waterbury, J.B., Herdman, M., Stanier, R.Y., 1979. Generic assignments, strain histories and properties of pure cultures of cyanobacteria. J. Gen. Microbiol. 111, 1-61.

Rodger, H.D., Turnbull, T., Edwards, C., Codd, G.A., 1994. Cyanobacterial (blue-green-algal) bloom associated pathology in brown trout, Salmo trutta L., in Loch Leven, Scotland. J. Fish Dis. 17, 177-181.

Sivonen, K., Jones, G., 1999. Cyanobacterial toxins. In: Chorus, I., Bartram, J. (Eds.), Toxic Cyanobacteria in Water. E\&FN Spon, London, pp. 41-111.

Snyder, G.S., Goodwin, A.E., Freeman, D.W., 2002. Evidence that channel catfish, Ictalurus punctatus (Rafinesque), mortality is not linked to ingestion of the hepatotoxin microcystin-LR. J. Fish Dis. 25, 275-285.

Spoof, L., Vesterkvist, P., Lindholm, T., Meriluoto, J., 2003. Screening for cyanobacterial hepatotoxins, microcystins and nodularin in environmental water samples by reversed-phase liquid chromatography-electrospray ionisation mass spectrometry. J. Chromatogr. A 1020, 105-119.

Svobodová, Z., Kaláb, P., Dusek, L., Vykosová, B., Kolárová, J., Janousková, D., 1999. The effect of handling and transport on the concentration of glucose and cortisol in blood plasma of common carp. Acta Vet. Brno $68,265-274$

Tencalla, F., 1995. Toxicity of cyanobacterial peptide toxins to fish. PhD Thesis. Swiss Federal Institute of Technology, Zurich.

Tencalla, F., Dietrich, D., 1997. Biochemical characterization of microcystin toxicity in trout (Oncorhynchus mykiss). Toxicon 35, 583-595.

Tencalla, F.G., Dietrich, D.R., Schlatter, C., 1994. Toxicity of Microcystis aeruginosa peptide toxin to yearling rainbow trout (Oncorhynchus mykiss). Aquat. Toxicol. 30, 215-224.

Toranzo, A.E., Nieto, F., Barja, J.L., 1990. Mortality associated with cyanobacterial bloom in farmed rainbow trout in Galicia (Northwestern Spain). Bull. Eur. Assoc. Fish Pathol. 10, 106-107.

Utkilen, H., Skulberg, O., Skulberg, R., Gjolme, N., Underdal, B., 2001. Toxic cyanobacterial blooms of inland waters in Southern Norway, 1978-1998. In: Chorus, I. (Ed.), Cyanotoxins. Springer-Verlag, Berlin, pp. 46-49. 